\title{
Unusual cause of menorrhagia
}

\author{
Charles Anwuzia-Iwegbu, Scott Akker
}

Department of Specialist Endocrine, Barts \& The Royal London, London, UK

\section{Correspondence to}

Dr Scott Akker,

scott.Akker@bartshealh.nhs.uk

\section{DESCRIPTION}

A 37-year-old woman presented to her general practitioner (GP) with a history of intermittent galactorrhoea and amenorrhoea. She reported intermittent expression $(5 \mathrm{~mL})$ from both breasts, which have been present following her last pregnancy 4 years ago. In addition she reported tension headaches with no visual disturbances and left-sided nasal obstruction which was treated with prescribed fluticasone nasal spray.

Following an episode of menorrhagia, the patient presented to her GP and routine blood tests were performed, which included haemoglobin $12.0 \mathrm{~g} / \mathrm{dL}$, mean corpuscular volume $81.4 \mathrm{fL}$, white cell count $8.9 \times 10^{9} / \mathrm{L}$, platelets $304 \times 10^{9} / \mathrm{L}$, sodium $143 \mathrm{mmol} / \mathrm{L}$, potassium $3.6 \mathrm{mmol} / \mathrm{L}$, serum luteinizing hormone level: $0.2 \mathrm{U} / \mathrm{L}(2.9-21.7 \mathrm{U} / \mathrm{L})$, serum follicle-stimulating hormone level: $10.1 \mathrm{U} / \mathrm{L}$ (2.5$19.5 \mathrm{U} / \mathrm{L})$, serum prolactin $3428 \mathrm{mU} / \mathrm{L}$ (25-629 U/L). The GP requested an MRI scan which revealed a $4.4 \times 4.6 \times 2.7 \mathrm{~cm}$ lesion filling the central sphenoid air sinus, pituitary lesion or nasal polyp (figure 1).

The patient reported a background of hypertension which is currently well controlled on amiloride $10 \mathrm{mg}$ once daily and lisinopril $20 \mathrm{mg}$ once daily.
She denies any endocrinopathies in her family history. She was referred to St Bartholomew's Hospital, endocrinology department and given a trial single dose of carbergoline $0.5 \mathrm{mg}$ which significantly suppressed the levels of prolactin from 3428 to $280 \mathrm{mU} / \mathrm{L}$. Nasal biopsy revealed null cell pituitary adenoma with a Ki67 index $<1 \%$.

Initially we were keen to manage this medically as the patient did not report any visual deficit. ${ }^{1}$ However, as she continued to report left nasal obstruction, spontaneous tension headaches and the issue of the prolactinoma penetrating the sellar floor and filling the central air sinus suggested that she may benefit from nasal debulking followed by trans-sphenoidal surgery for pituitary debulking. ${ }^{1}$

Overall, this was a very interesting case; normally such patients would be treated medically; however, due to the size and impact the pituitary mass had on the patient's quality of life the overall decision made by the patient and multidisciplinary team to opt for surgery which eliminated any future risk of optic chiasmal compression and improved patient's quality of life. There were no complications during the surgical procedures and the patient's symptoms have fully resolved.
To cite: Anwuzia-Iwegbu C, Akker S. BMJ Case Rep Published online: [please include Day Month Year] doi:10.1136/bcr-2012008285

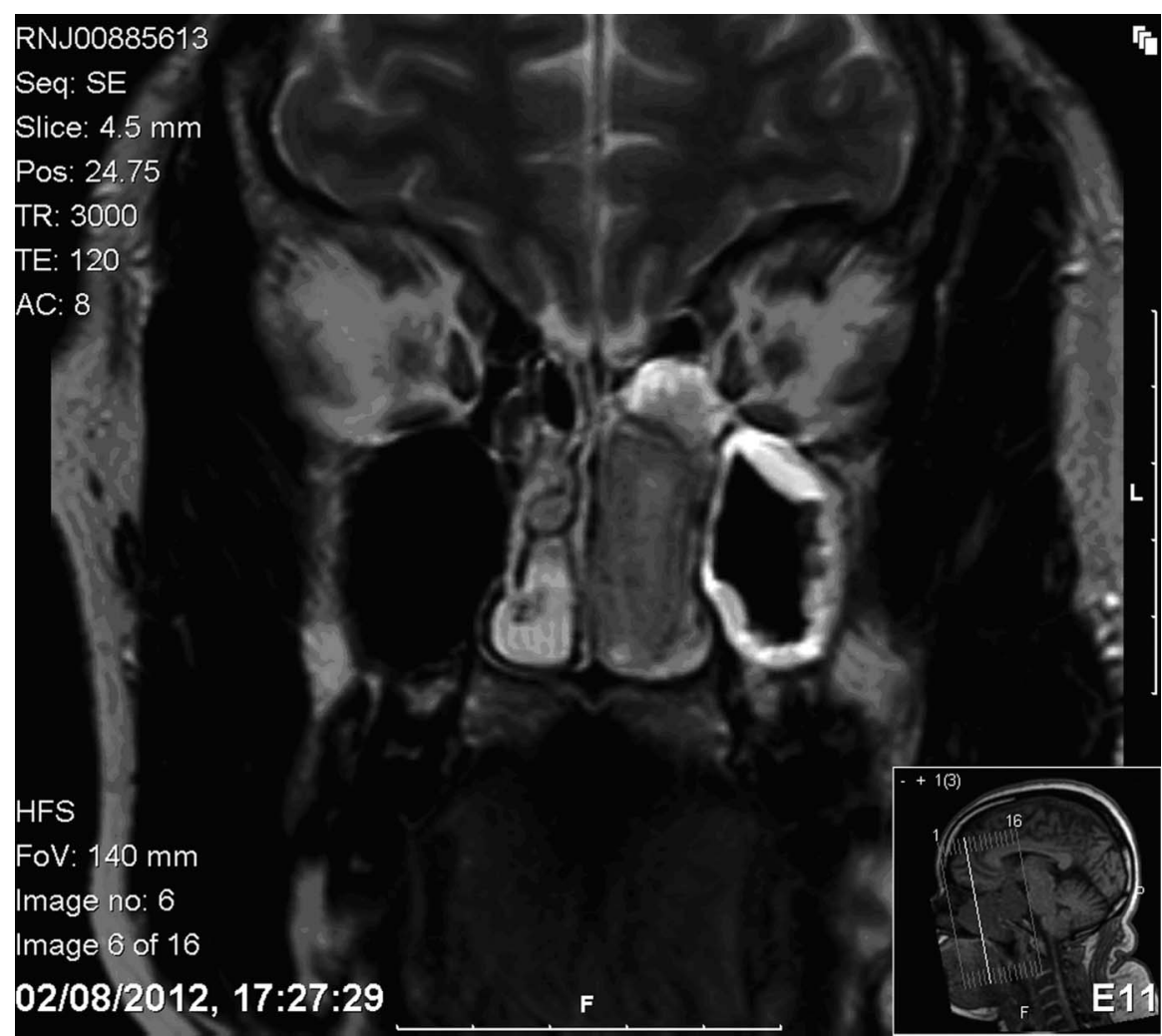

Figure 1 MRI scan which reveals a $4.4 \times 4.6 \times 2.7 \mathrm{~cm}$ lesion filling the central sphenoid air sinus. 


\section{Learning points}

- In a patient with inappropriate galactorrhoea—check the prolactin. $^{1}$

- MRI scanning is essential. ${ }^{1}$

- Trial of cabergoline therapy may help shrink tumour avoiding surgical intervention. ${ }^{1}$

Acknowledgements The authors acknowledges Dr Ali Mian, Dr Harinder Chahal, Dr Shazia Hussain, Dr Eleftheria Pantellou.
Contributors CA-I compiled the image report. SA proof read the report and carried out literature search.

Competing interests None.

Patient consent Obtained.

Provenance and peer review Not commissioned; externally peer reviewed.

\section{REFERENCE}

1 Melmed S, Kleinberg D. Pituitary masses and tumors. In: Kronenberg HM, Melmed S, Polonsky KS, Larsen PR, eds. Williams textbook of endocrinology. 12th edn. Philadelphia, PA: Saunders Elsevier, 2011, chapter 9.

Copyright 2013 BMJ Publishing Group. All rights reserved. For permission to reuse any of this content visit http://group.bmj.com/group/rights-licensing/permissions.

BMJ Case Report Fellows may re-use this article for personal use and teaching without any further permission.

Become a Fellow of BMJ Case Reports today and you can:

- Submit as many cases as you like

- Enjoy fast sympathetic peer review and rapid publication of accepted articles

- Access all the published articles

- Re-use any of the published material for personal use and teaching without further permission

For information on Institutional Fellowships contact consortiasales@bmjgroup.com

Visit casereports.bmj.com for more articles like this and to become a Fellow 